\title{
建築廃棄物と工事工程の関連性に関する研究 VOLUME AND CONTENTS OF BUILDING CONSTRUCTION WASTES IN RELATION TO CONSTRUCTION PROCESS
}

\author{
竹尾 健 一*
}

\section{Kenichi TAKEO}

\begin{abstract}
To better plan and control building construction wastes, exact patterns of waste emission in relation to construction process must be elucidated. Using survey data on numerous executed projects, the author has clarified that construction time governs the pattern, that more than half of the total wastes is emitted after the time when finish work is at the highest so that the crucial part of waste control to enhance 3R exists in how to deal with finish work mixed wastes amounting $80 \%$ of the total and so on, all of which are fundamental to wastes planning and control methodology.
\end{abstract}

Keywords : building construction waste, wastes emission pattern, 3R, zero emission, construction process 建築廃棄物，廃棄物発生パターン，3R，ゼロエミッション，工事工程

\section{1. はじめに}

建築施工時に発生する廃棄物（以下、建築廃棄物）は、同一種類 が一定の頻度で発生する他産業の廃棄物とは異なり、工事の進捗に 伴って多種多様に変化する。躯体工事の期間ではコンクリートの残 材や鉄筋の端材、型枠に使用されるべニヤの端材などが多く、その 種類は比較的限定的である。しかし仕上工事の期間には使用される 建築資材の種類が多様化し、それに伴い非常に多くの種類の廃棄物 が発生する。発生量も杭・山留・土工事から躯体工事までは比較的 少なく、仕上工事の開始に伴って徐々に増加する傾向がある。廃棄 物を分別L 3 R (Reduce：発生抑制、Reuse：再使用、Recycle： 再資源化）を推進するためには、廃棄物の種類や発生量の変化に合 わせた分別ヤードの整備や分別容器の設置が必要である。また工程 管理を行う上で、竣工間際に大量に発生する廃棄物を迅速かつスム ーズに排出することが、仕上工事の最終段階を無䭾なく進めるポイ ントになる。以上のように、廃棄物計画を行うためには発生量の把 握とともに工事工程との関連性を考慮する必要があると考える。

建築廃棄物の排出時期に言及した既往研究としては、建築生産プ ロセスにおける混合廃棄物の量、排出頻度、 $\mathrm{CO}_{2}$ 排出量について考 察を行った名知らによる研究 ${ }^{1}$ 、、解体工事における廃棄物種類と発 生時期に関する調查研究を行った小川らによる研究 ${ }^{2)}$ などがある。 しかし工事工程との関連性に関する研究成果は発表されていない。 本研究では実績データを基に、建築廃棄物と工事工程の関連性を 明らかにすることを目的とし、以下の項目について考察を行う。

（1）過去の廃棄物の排出実績を基に、工程進捗と廃棄物発生量の推 移の関係（以下、廃棄物発生パターン）を明らかにし、建築種別 （工期の長さ、地下階の有無、構造、建物用途）ごとの傾向につ
いて考察する。

（2）具体的な物件のデータを基に、工事期間を(1)杭・山留・土工事、 (2)躯体工事、(3)躯体+仕上工事、(4)仕上工事の 4 種類に区分し、 各工事期間と廃棄物発生量の割合の関連性について分析する。

（3）上記について建物用途と構造の組合せによる比較、工期短縮を 目的に採用する特殊構工法による影響について考察する。

（4）ゼロエミッションモデル現場の廃棄物実績を基に、具体的な廃 棄物種類ごとの発生パターンについて考察する。

\section{2. 建築種別ごとの廃棄物発生パターンの傾向}

\section{1 分析データの概要}

筆者が所属する建設会社の施工物件のうち、2007年 4 月から 2010 年 3 月に竣工した首都圈を所在地とする新築工事の中から計 88 件 を任意に抽出し、廃棄物の排出実績を集計した。物件は新築工事の みの契約物件を対象とし、解体工事が同時進行したものは対象外と した。サンプルデータの内訳を表 1 に示す。物件のデータは工期の 長さによって 12 ヶ月以下 (工期区分 1 )、 24 ヶ月以下 (工期区分 2 )、 24 ケ月超（工期区分 3 ）の 3 種類、構造に関しては $\mathrm{S}$ 造、 $\mathrm{RC}$ 造、 $\mathrm{SRC}$ 造の 3 種類に分け、また、山留・土工事による工程への影響を 考慮して、地下階の有無の 2 種類に区分した。本分析に用いた工期

表 1 サンプルデータの内訳（件数）

\begin{tabular}{|c|c|c|c|c|c|c|c|c|c|c|}
\hline 構造 & \multicolumn{3}{|c|}{ S造 } & \multicolumn{3}{|c|}{$\mathrm{RC}$ 造 } & \multicolumn{3}{|c|}{ SRC造 } & \multirow[b]{2}{*}{ 合計 } \\
\hline 地下有無 & $\begin{array}{l}\text { 地 } \\
\text { 下 } \\
\text { 無 }\end{array}$ & $\begin{array}{l}\text { 地 } \\
\text { 下 } \\
\text { 有 }\end{array}$ & 計 & $\begin{array}{l}\text { 地 } \\
\text { 下 } \\
\text { 無 }\end{array}$ & $\begin{array}{l}\text { 地 } \\
\text { 下 } \\
\text { 有 }\end{array}$ & 計 & $\begin{array}{l}\text { 地 } \\
\text { 下 } \\
\text { 無 }\end{array}$ & $\begin{array}{l}\text { 地 } \\
\text { 下 } \\
\text { 有 }\end{array}$ & 計 & \\
\hline 工期区分1 (12ヶ月以下) & 10 & 2 & 12 & 13 & 1 & 14 & 2 & 0 & 2 & 28 \\
\hline 工期区分2( 24ヶ月以下 & 5 & 11 & 16 & 7 & 11 & 18 & 3 & 4 & 7 & 41 \\
\hline 工期区分3 (24ヶ月超) & 0 & 8 & 8 & 0 & 6 & 6 & 0 & 5 & 5 & 19 \\
\hline 計 & 15 & 21 & 36 & 20 & 18 & 38 & 5 & 9 & 14 & 88 \\
\hline
\end{tabular}

\footnotetext{
$*$ 大成建設(侏環境本部環境開発部 工修

Environmental Development Dept. Environment Div., Taisei Corporation, M. Eng.
} 
は新築工事の着工から竣工までの期間とし、新築工事前の準備工事 や竣工後のテナント工事などの期間は含めない。建設污泥は発生し た直後に排出されることが多く、現場での $3 \mathrm{R}$ 対策ができないこと から対象廃棄物から除外した。また廃油、廃アルカリ、廃酸、特別 管理廃棄物も特殊な条件の現場でのみ排出されることから対象廃棄 物から除外した。データは現場で発行した電子マニフェスト注 1) か ら取得し、紙マニフェストからの転記ミスや入力ミスによる誤差を 限りなく排除した。また比重の大きいコンクリートや、逆に小さい 紙くずのように比重の大小によって見た目の感覚と数值に相違が生 じないように、数值データは重量数值に変換せず電子マニフェスト に記録されている見かけの体積 $\left(\mathrm{m}^{3}\right)$ を使用した。

\section{2 データ集計および分析方法}

工期の異なる各物件を工程の相対的な進捗度を指標に用いて比較 分析するため、全工期を $100 \%$ として工程を 10\%間隔に分割し、そ の期間の廃棄物発生量を集計した。サンプルデータの集計手順は以 下の通りである (表 2 参照)。(1)全工期を $100 \%$ とした時の各集計月 の相対的な進捗率（以下、工程進捗率）を求める。(2)月別の廃棄物 発生量を積算し、全発生量を $100 \%$ とした時の各期間別発生量の割 合（以下、発生量割合）を求める。(3)工程進捗率 $10 \%$ ごとの発生量 割合の累計を、前後の工程進捗率による比例計算により算出する。

\section{3 全体データによる廃棄物発生パターンの比較 \\ （1）廃棄物発生パターンの工期区分別による特徵}

図 1 に工期区分別の廃棄物発生パターンの比較を示す。また各集 計データの分散範囲を図 2 に示し、それぞれの平均值および標準偏 差を表 3 に示寸。廃棄物の発生量割合の上昇傾向を見ると、最も早 い段階から発生量割合の上昇傾向が見られるのは、工期が短い工期 区分 1 であり、工期区分 2 、工期区分 3 の順に発生量割合の上昇時 期が徐々に遅くなっていることが分かる。図 2 のデータの分散範囲 にも同じ傾向を確認することができる。つまり工期が長く規模の大 きい物件ほど、竣工前に廃棄物の発生が集中していると考えられる。 最も大きな差が発生している工程進捗率 $80 \%$ 時点に着目すると、工 期区分 1 では $76 \%$ の廃棄物の排出されているのに対して、工期区分 3 では $49 \%$ の廃棄物しか排出しておらず、残りの工期 $20 \%$ の間に $51 \%$ の廃棄物を排出していることが分かる。一般的にこの時期は受 電を控えた仕上工事の最盛期であり、現場の工程管理および品質管 理において最も重要な局面を迎える時期と重なる。

\section{（2）廃棄物発生パターンの地下階有無別による特徵}

地下階の有無別の廃棄物発生パターンの比較を図 3 に示す。工程 進捗率が $50 \%$ までは発生量割合に相違は認められないが、工程進捗 率が $80 \%$ の時点になると最大 $14 \%$ の差が現れている。表 1 のサン プルデータを見ると地下階の無い物件は、全体工期も比較的短い物 件が多いことが分かる。このように地下階の有無と工程の長さが相 互に関係していることから、(1)の分析結果と同様に、工期が短い物 件（地下階の無い物件）ほど発生量割合の上昇が早い時期に始まる 傾向があると考えられる。地下階の有無によって躯体工事と仕上工 事の開始時期（躯体工事：基礎工事開始時、仕上工事：内装仕上開 始時）に相違があるかどうかを確認するため、全サンプルデータの うち工程情報を得ることができた 50 件（地下無し： 24 件、地下有 り：26 件）について分析を行なった。図 4 (地下階無し) および図 5 （地下階有り）に各物件の全工期を $100 \%$ とした時の躯体工事と
表 2 発生量割合の計算例

\begin{tabular}{|c|c|c|c|c|c|c|c|c|c|c|c|c|c|c|c|c|c|}
\hline 集計月 & 0 & & 1 & & 2 & & & 3 & & 4 & & & 5 & & 6 & & 7 \\
\hline 工程進捗率 & $0 \%$ & $10 \%$ & $14 \%$ & $20 \%$ & $29 \%$ & $30 \%$ & $40 \%$ & $43 \%$ & $50 \%$ & $57 \%$ & $60 \%$ & $70 \%$ & $71 \%$ & $80 \%$ & $86 \%$ & $90 \%$ & $100 \%$ \\
\hline 発生量 $(\mathrm{m} 3)$ & & 10 & & 2 & & & 3 & & 8 & & & 16 & & 38 & & 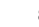 & 8 \\
\hline 発生量割合 & & $12 \%$ & & 29 & & & $4 \%$ & & 9 & & & $19 \%$ & & 45 & & & $9 \%$ \\
\hline 発生量割合の累計 & & $8 \%$ & & $13 \%$ & & $14 \%$ & $17 \%$ & & $22 \%$ & & $31 \%$ & $44 \%$ & & $73 \%$ & & $93 \%$ & $100 \%$ \\
\hline
\end{tabular}

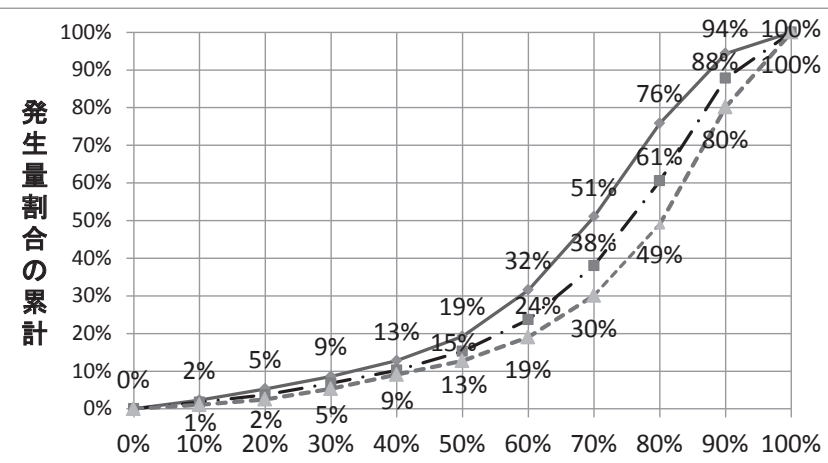

工程進捗率

—工期区分1 —. 工期区分2 - - 工期区分3

図 1 工期区分別の廃棄物発生パターンの比較

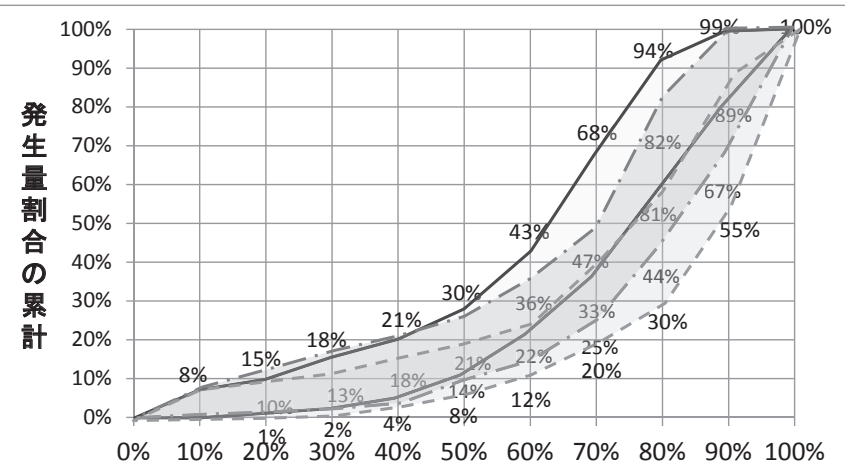

工程進捗率

$\square$ 工期区分1

図 2 工期区分別の廃棄物発生パターン（データ分散範囲）

表 3 発生量割合の累計の平均值と標準偏差

\begin{tabular}{|c|c|c|c|c|c|c|c|c|c|c|}
\hline \multicolumn{2}{|c|}{ 工程進捗率 } & $10 \%$ & $20 \%$ & $30 \%$ & $40 \%$ & $50 \%$ & $60 \%$ & $70 \%$ & $80 \%$ & $90 \%$ \\
\hline \multirow{2}{*}{ 工期区分1 } & 平均 & $2 \%$ & $5 \%$ & $9 \%$ & $13 \%$ & $19 \%$ & $32 \%$ & $51 \%$ & $76 \%$ & $94 \%$ \\
\cline { 2 - 10 } & 標準偏差 & $3 \%$ & $4 \%$ & $4 \%$ & $4 \%$ & $5 \%$ & $6 \%$ & $8 \%$ & $9 \%$ & $5 \%$ \\
\hline \multirow{2}{*}{ 工期区分2 } & 平均 & $2 \%$ & $4 \%$ & $7 \%$ & $10 \%$ & $15 \%$ & $24 \%$ & $38 \%$ & $61 \%$ & $88 \%$ \\
\cline { 2 - 10 } & 標準偏差 & $2 \%$ & $3 \%$ & $4 \%$ & $5 \%$ & $5 \%$ & $5 \%$ & $6 \%$ & $9 \%$ & $8 \%$ \\
\hline \multirow{2}{*}{ 工期区分3 } & 平均 & $1 \%$ & $2 \%$ & $5 \%$ & $9 \%$ & $13 \%$ & $19 \%$ & $30 \%$ & $49 \%$ & $80 \%$ \\
\cline { 2 - 10 } & 標準偏差 & $2 \%$ & $2 \%$ & $3 \%$ & $4 \%$ & $4 \%$ & $4 \%$ & $6 \%$ & $9 \%$ & $8 \%$ \\
\hline
\end{tabular}

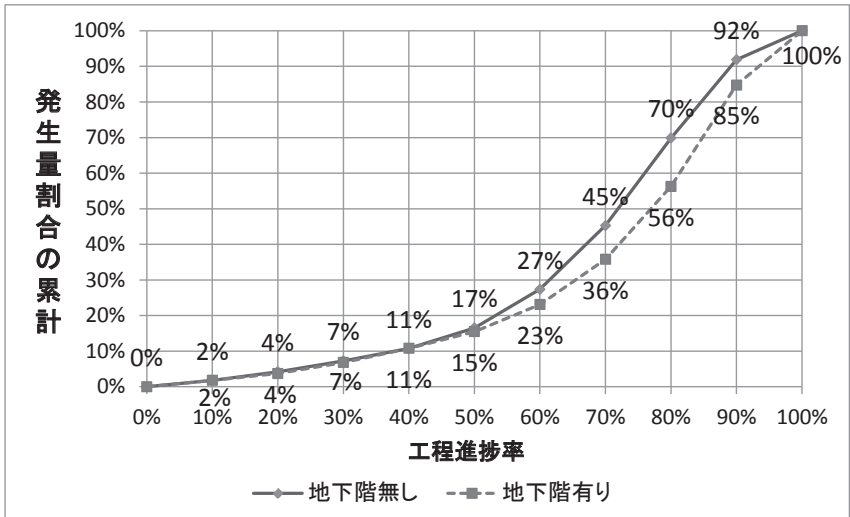

図 3 地下階有無別の廃棄物発生パターンの比較 
仕上工事の開始時期を示す。地下階無しの場合の躯体工事開始時期 の平均は工程進捗率 $19 \%$ 時点、地下階有りの場合は $25 \%$ 時点と後 者の方が遅くなっている。これは地下階が有る場合、山留工事およ び土工事の期間が長くなり、その分躯体工事の開始時期が遅くなる ためであると考えられる。一方、多くの廃棄物が発生する仕上工事 の開始時期は双方とも平均 $55 \%$ ～ $56 \%$ の時点であり、大きな差異は 認められない。

\section{（3）廃棄物発生パターンの構造別による特徵}

構造別よる廃棄物発生パターンの比較を図 6 に示す。 $\mathrm{S}$ 造と $\mathrm{RC}$ 造の廃棄物発生パターンはほぼ同じ傾向になっている。また SRC 造においても発生量割合の上昇時期は他の構造よりやや遅いものの、 全体的には大きな差異は認められない。

\section{（4）廃棄物発生パターンの建物用途別による特徵}

建物用途別よる廃棄物発生パターンの比較を図 7 に示寸。サンプ ルデータの建物用途は合計で 13 種類（社内で規定した種類）に分 散していたため、ある程度のサンプル数がそろった 4 種類の建物用 途（事務所： 30 件、集合住宅: 16 件、教育施設 : 9 件、工場 : 8 件) について分析を行なった (表 4 参照)。工場の発生量割合の上昇が他 の建物用途よりやや早い時期になっているが、それ以外については 建物用途による差異は認められない。

以上の結果より、廃棄物の発生パターンに大きな影響を与える条 件は工期の長さであると考えられる。

\section{3．個別物件データによる詳細分析}

\section{1 物件データの抽出}

建物用途と構造の組合せによる廃棄物発生パターンを比較するた め、前述の建物用途（事務所、集合住宅、教育施設、工場）の中か ら個別の物件データを抽出して分析を行った。表 4 に各建物用途と 構造の組合せによる物件データのサンプル数と抽出対象を示す。工 期の長さの条件を同じにするため、事務所（S 造）、集合住宅（RC 造)、教育施設（RC 造） は工期区分 2 、工場（ $\mathrm{S}$ 造） は工期区分 1 の物件を抽出対象とし、工程情報を得られた物件 (事務所: 12 件中 6 件、集合住宅： 5 件中 5 件、教育施設： 6 件中 4 件、工場： 6 件 中 5 件）を抽出した。また工期短縮を目的に採用される特殊構工法 の影響について検証を行うため、特殊構工法を採用した物件を前述 のサンプルデータの中から抽出した。工期短縮を目的とした特殊構 工法には(1)逆打工法（本設の床および梁を山留め支保工として利用 し、掘削しながら地下躯体と地上躯体を同時施工する工法)、(2) 1 階 床先行工法（掘削終了後、1 階床を先行構築し地上躯体と地下躯体 を同時施工寸る工法)、(3) PCa 工法（工場生産した PCa 躯体部材を 現場で組立てる工法) などがある。その中から逆打工法を採用した 3 物件（逆打 $+\mathrm{PCa} / \mathrm{RC}$ 造 : 2 件、逆打 $/ \mathrm{S}$ 造 : 1 件）を抽出して 分析を行った。表 5 に各物件の建築概要を示寸。

\section{2 工事期間区分の定義}

建築の施工は、杭工事 $\rightarrow$ 山留工事 $\rightarrow$ 土事 $\rightarrow$ 躯体工事 $\rightarrow$ 仕上工事 の順番に進められるのが一般的である。また躯体工事と仕上工事に ついては上階と下階で同時進行する重複期間がある。図 8 に示すよ うに各工事が進捗する工事期間は主たる工事の開始や区切りによっ て(1)杭・山留・土工事（着工～基礎躯体開始)、(2)躯体工事（基礎躯 体開始～仕上開始)、(3)躯体 + 仕上工事（仕上開始～上棟)、(4)仕上

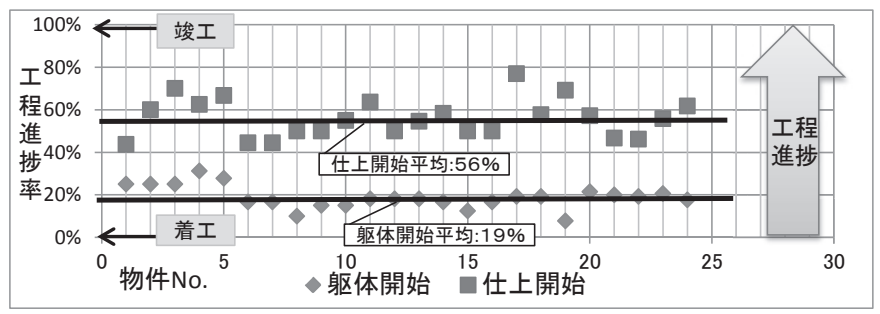

図 4 各物件の躯体工事および仕上工事開始時期（地下階無し）

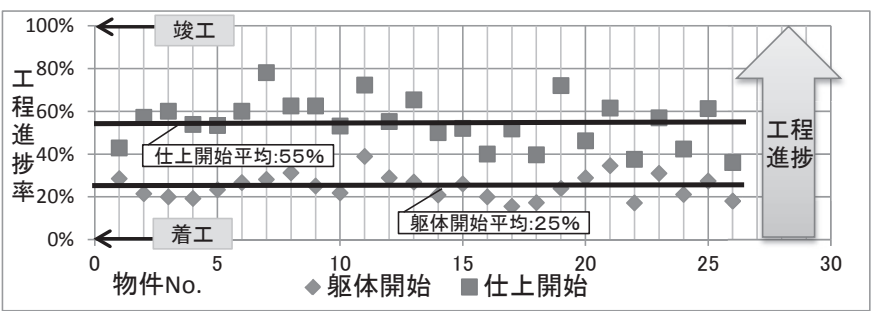

図 5 各物件の躯体工事および仕上工事開始時期（地下階有り）

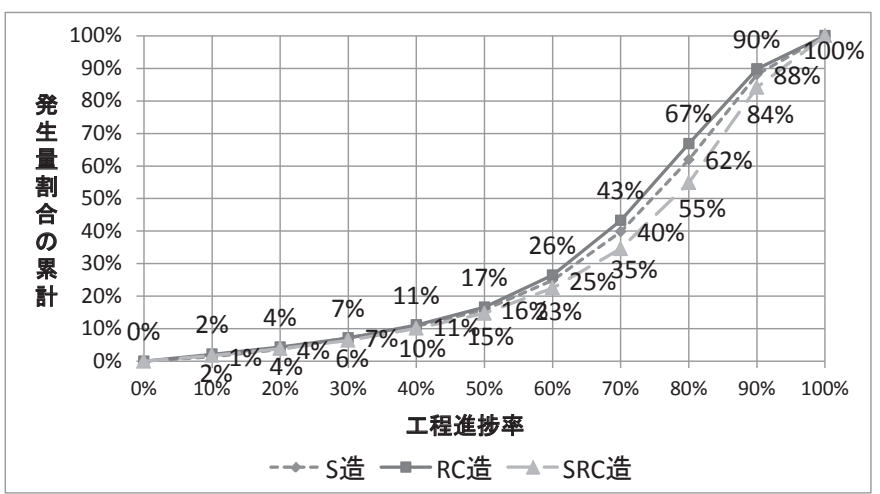

図 6 構造別の発生パターンの比較

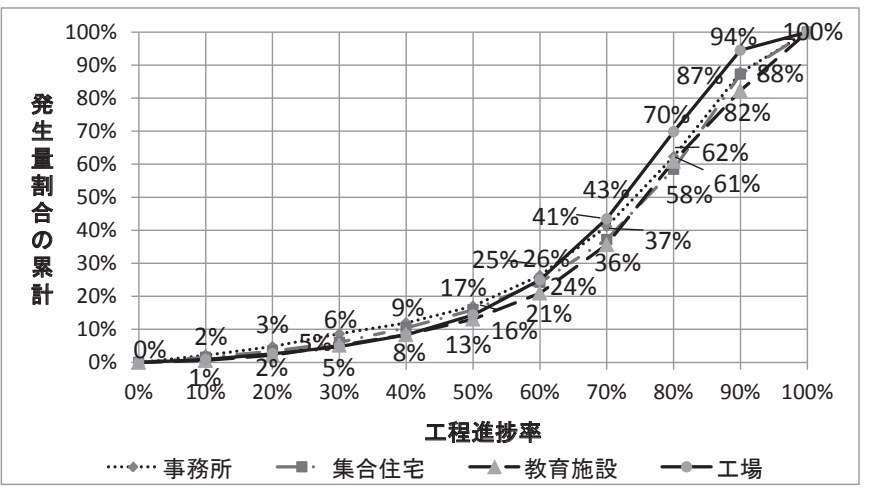

図 7 建物用途別の発生パターンの比較

表 4 物件データのサンプル数と抽出条件

\begin{tabular}{|c|c|c|c|c|c|c|c|c|c|c|}
\hline & \multicolumn{3}{|c|}{ 工期区分1 } & \multicolumn{3}{c|}{ 工期区分2 } & \multicolumn{3}{c|}{ 工期区分3 } & \multirow{2}{*}{ 合計 } \\
\cline { 2 - 11 } & S造 & RC造 & SRC造 & S造 & RC造 & SRC造 & S造 & RC造 & SRC造 & \\
\hline 事務所 & 3 & 3 & 1 & 12 & 3 & 2 & 6 & 0 & 0 & 30 \\
\hline 集合住宅 & 0 & 2 & 0 & 1 & 5 & 2 & 0 & 5 (逆打) 1 & 16 \\
\hline 教育施設 & 0 & 0 & 1 & 1 & 6 & 1 & 0 & 0 & 0 & 9 \\
\hline 工場 & 6 & 1 & 0 & 1 & 0 & 0 & 0 & 0 & 0 & 8 \\
\hline
\end{tabular}

工事（上棟～竣工）の 4 つの区分（以下、工事期間区分）に分類す ることができる。各工事期間では搬入される資材に違いがあり、廃 棄物の発生量やその内容に相違があると考えられる。

\section{3 建物用途別、構造別の廃棄物の発生原単位}

建物用途、構造の違いによる廃棄物の発生量の相違を確認するた め、(社) 建築業協会が発表している延床面積あたりの廃棄物発生量 (以下、発生原単位) ${ }^{3)}$ を図 9 に示寸。建物用途別では事務所、集 合住宅、教育施設については発生原単位に大きな差異が見られない。 一方、工場の発生原単位は他の建物用途の半分程度の数值となって 
いる。構造別の発生原単位は、 $\mathrm{RC}$ 造がやや大きい数值になってい るが全体的には大きな差異は見られない。以上のことより、抽出さ れた物件データの中では工場を除いて廃棄物の発生原単位に大きな 差が無いと仮定することができる。この結果を踏まえて前述の各物 件について分析を行う。

\section{4 各物件データの工事期間区分別の発生量割合の比較 (1) 事務所、集合住宅、教育施設}

発生原単位に大きな差が見られなかった事務所、集合住宅、教育 施設について分析を行う。図 10、図 13、図 16 に各建物用途の物件 ごとに、各工事期間区分に要した期間の割合を示す。 3 つの建物用 途の杭・山留・土工事の工事期間は全工期の 12 29\%であり、平均 的にはおよそ $20 \%$ 前後である。そのうち事務所 6 、集合住宅 4 、教 育施設 2 、教育施設 4 は杭工事が無いため、他の物件よりも比較的 短くなっている。躯体工事の期間（仕上工事との重複期間を含む） は 31〜 59\%である。また仕上工事の期間（躯体工事との重複期間を 含む）は 37〜 54\%である。仕上工事の開始時期を見ると工程進捗率 $47 \sim 63 \%$ の時点であり、平均的には $50 \sim 60 \%$ の時点である。図 11 、 図 14、図 17 に各工事期間に排出された廃棄物の発生量割合を示す。 杭・山留・土工事の期間の廃棄物の発生量割合は $2 \sim 10 \%$ であり、 非常に少ないことが分かる。躯体工事の廃棄物の発生量割合は教育 施設 3 を除いて 7 21\%であり、平均的には $15 \%$ 程度である。仕上 工事期間（躯体工事との重複期間を含む）の廃棄物の発生量割合は 事務所で 81〜84\%、集合住宅で 74〜85\%、教育施設は 66 91\%で あり、平均的には $80 \%$ 程度を占めると考えられる。躯体工事との重 複期間は、躯体工事による発生量割合が小さいことから仕上工事に よるものが多くを占めると予想される。

多くの廃棄物が発生する工程進捗率 $50 \%$ の時点以降の発生量割 合（全廃棄物発生量を $100 \%$ とする）の推移を図 12 、図 15 、図 18 に示す。工程進捗率 80〜90\%の時点で発生量割合がピークとなって いる物件が多く、その発生量割合は全廃棄物の $30 \sim 40 \%$ 程度となっ ている。特に集合住宅は発生量割合の推移が一定である。発生量割
合のピークが 70 ～80\%の時点となっている事務所 3 と教育施設 1 の物件は受電時期（各 78\%、77\%）が比較的早い時期であり、その 他の物件よりも早い段階で廃棄物の発生量が増加している。一方、 事務所 2 、事務所 5 、教育施設 4 は発生量割合のピークが 90〜 $100 \%$ の時点であり、竣工の直前に発生量割合のピークが見られる。受電 時期がやや遅い時期 ( $85 \%$ 以上) であることの影響が考えられるが、 同じく受電時期が遅い事務所 1,4 、集合住宅 1,4 、教育施設 2,3

表 5 物件データの建築概要
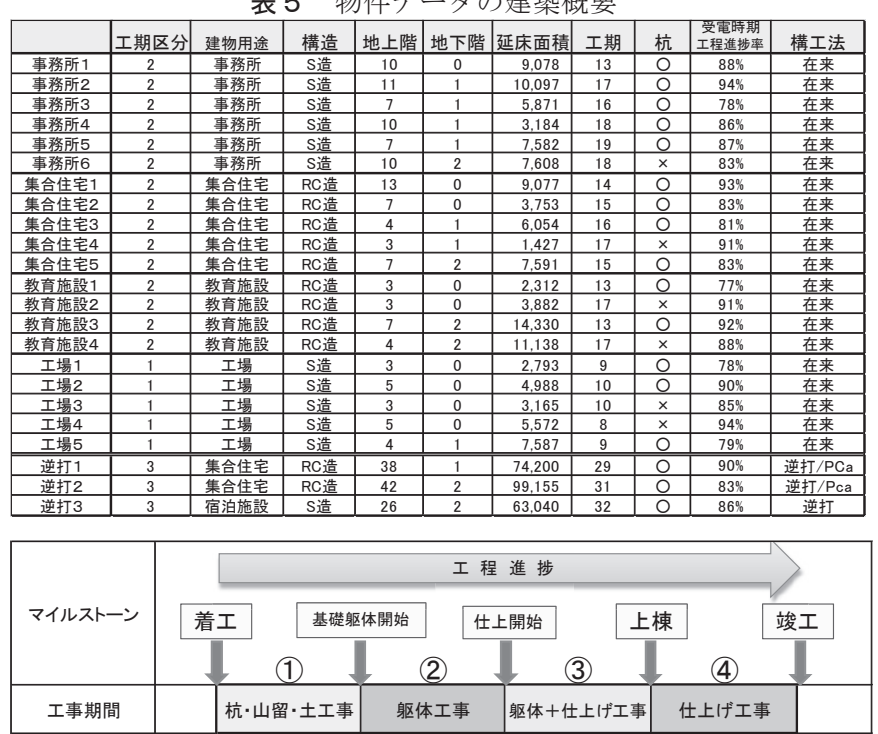
図 8 建築施工の工事期間の構成
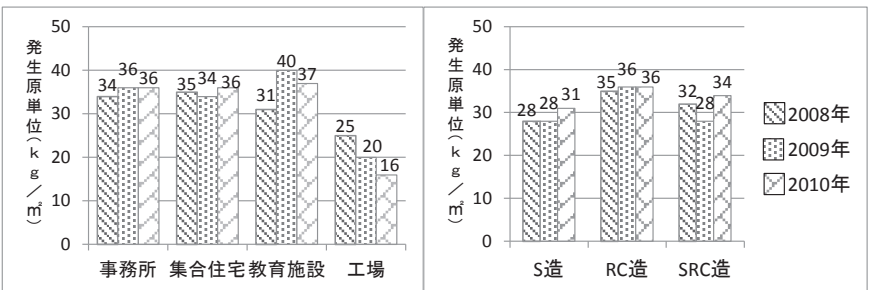

図 9 建物用途、構造別の発生原単位（建築業協会報告書上り）

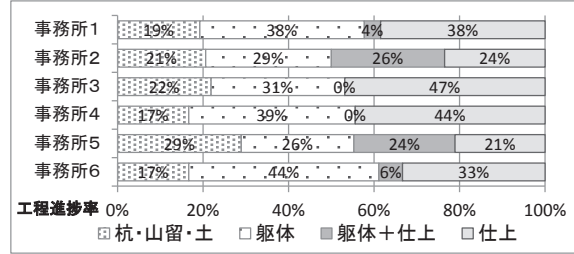

図 10 工事期間区分の割合（事務所）

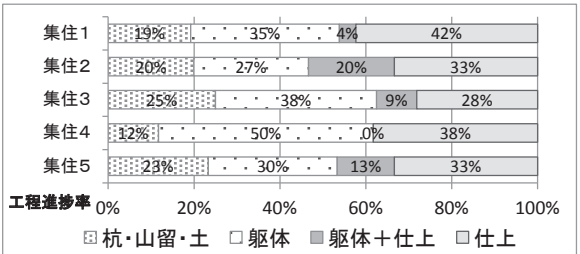

図 13 工事期間区分の割合 (集合住宅)

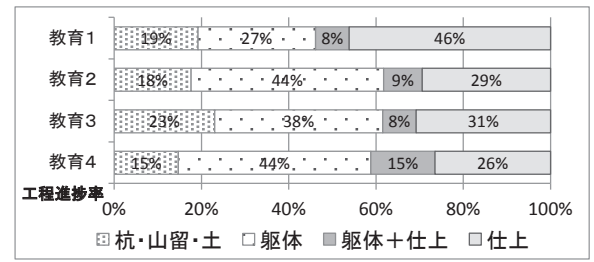

図 16 工事期間区分別の割合（教育施設）
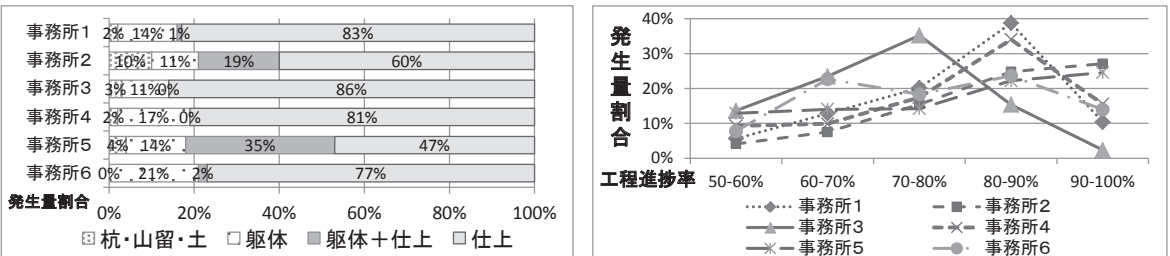

図 11 工事期間区分別の発生量割合（事務所）図 12 進捗率 50\%以降の発生量割合（事務所）
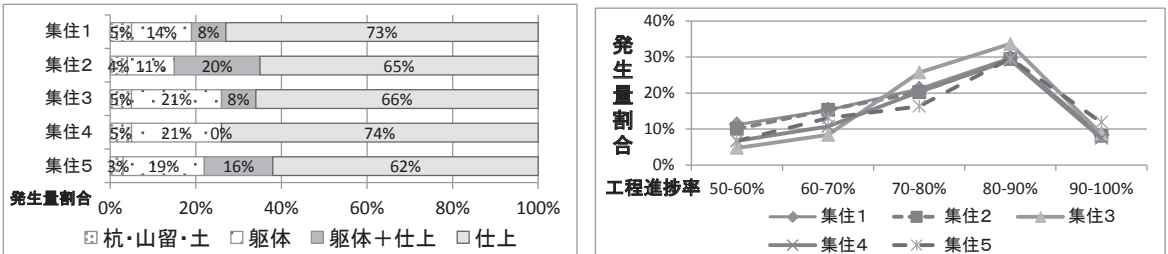

図 14 工事期間区分別の発生量割合 (集合住宅) 図 15 進捗率 $50 \%$ 以降の発生量割合(集合住宅)
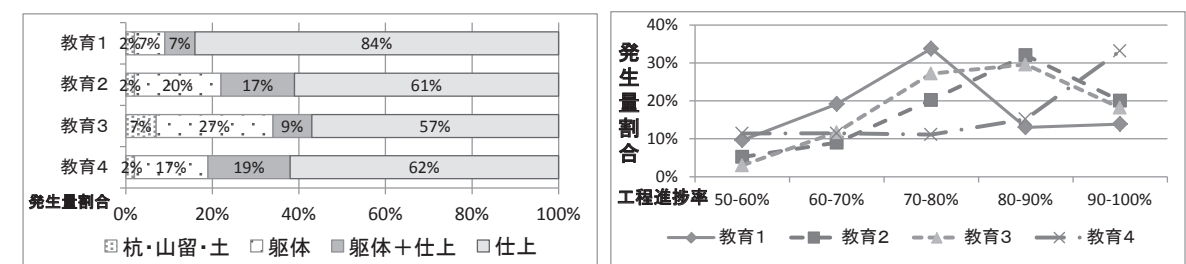

図 17 工事期間区分別の発生量割合 (教育施設) 図 18 進捗率 $50 \%$ 以降の発生量割合 (教育施設) 


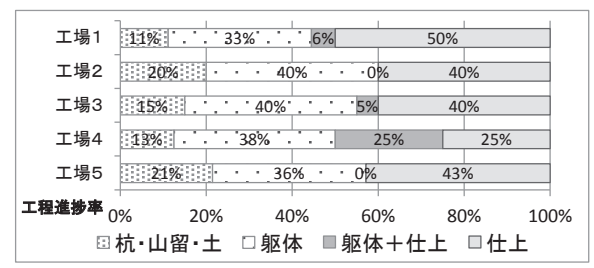

図 19 工事期間区分別の割合（工場）

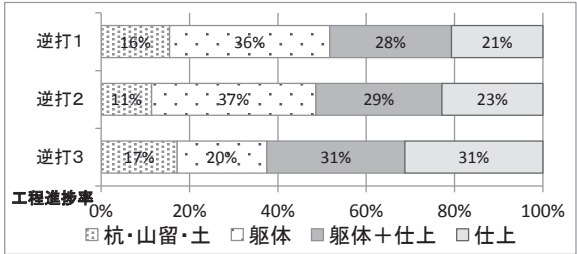

図 22 工事期間区分別の割合（逆打）

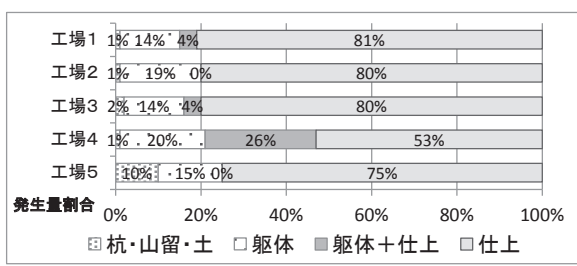

図 20 工事期間区分別の発生量割合 (工場)

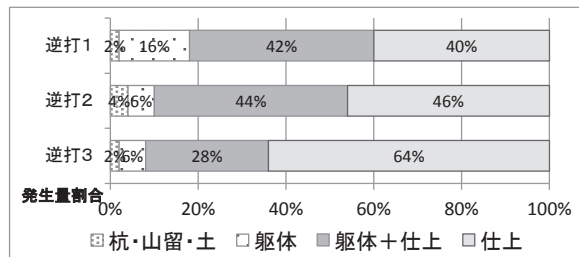

図 23 工事期間区分別の発生量割合（逆打）

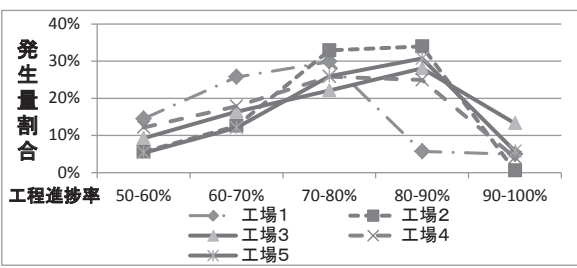

図 21 進捗率 $50 \%$ 以降の発生量割合（工場）

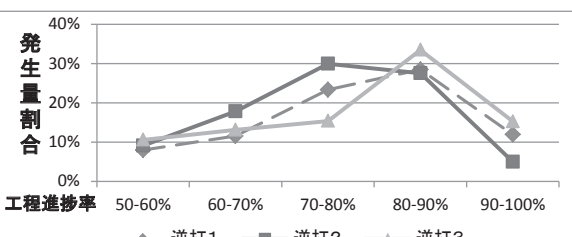

$\longrightarrow$ - 逆打1 - 一逆打 2 —-逆打了

図 24 進捗率 50\%以降の発生量割合（逆打）
ではこの傾向は見られず、これらの物件の特性であると考えられる。

以上の結果から、廃棄物の発生原単位が同程度の事務所、集合住 宅、教育施設は、工程進捗率 50 60\%の時点から仕上工事（躯体工 事との重複を含む）が開始され、仕上工事期間中に廃棄物の約 $80 \%$ が発生していることが確認された。また平均的には工程進捗率 80 〜 90\%の時点で廃棄物の発生量割合がピークを迎え、受電の時期が 早い物件は発生量のピークが早くなる傾向があることが分かった。

\section{（2）工場}

他の建物用途よりも廃棄物の発生原単位が小さい工場について分 析を行う。図 19、図 20 にそれぞれ各物件の工事期間区分の割合と 廃棄物の発生量割合を示す。工場のサンプル物件は工場 5 を除いて 地下階が無く、また工場 3 と工場 4 は杭工事が無いため杭・山留・ 土工事の工事期間が、事務所や集合住宅よりもやや短い傾向が見ら れる。仕上工事（躯体工事との重複を含む）の開始時期は工程進捗 率 $37 \sim 52 \%$ の時点とやや早いが、仕上工事期間の廃棄物の発生量割 合は他の建物用途と同様に $80 \%$ 程度を占めている。工程進捗率 $50 \%$ の時点以降の発生量割合の推移を図 21 に示寸。工場 1 を除き、発 生量割合のピークは工程進捗率 80 90\%の時点であるが、その前の 期間（70～80\%）も比較的高い割合になっている。この傾向は発生 量割合のビークが工程進捗率 70 〜 80\%である工場 1 でも確認でき る。以上の結果から、工場についても他の建物用途と同様に仕上工 事からの廃棄物の発生が大半を占めることが分かった。しかし、発 生のピークとなる時期は短期間に集中寸るのではなく徐々に増加す る傾向があることが確認された。また廃棄物の発生原単位が他の建 物用途の半分程度であることを考慮すると、排出のピーク時におけ る廃棄物管理は比較的容易であると想像される。

\section{（3）特殊構工法（逆打工法）}

工期の短縮を目的に採用される特殊構工法のうち、逆打工法およ び PCa 工法を採用した物件について分析を行った。逆打 $1 、 2$ は $\mathrm{PCa}$ による積層工法注 2$)$ と逆打工法を採用した RC 造の集合住宅、 逆打 3 は逆打工法を採用した $\mathrm{S}$ 造の宿泊施設である。図 22 、図 23 にそれぞれ各物件の工事期間区分の割合と廃棄物の発生量割合を示 す。仕上工事の開始時期は、逆打 1 と逆打 2 では工程進捗率 $52 \%$ 、 $48 \%$ の時点、逆打 3 では $37 \%$ の時点である。これらの物件では基準 階から仕上工事が開始されており、物件 1 、物件 2 では 7 階以降、 物件 3 では 4 階以降が基準階であるため、物件 3 の方が早い時期に なっていると考えられる。3つの物件の仕上工事期間の発生量割合
は 82 92\%であり、在来工法の物件よりも割合が高い。これは逆打 工法の採用により在来工法よりも躯体と仕上工事の重複期間が長く なることが影響していると考えられる。工程進捗率 $50 \%$ 時点以降の 発生量割合の推移を図 24 に示す。図 15 （在来工法の集合住宅）と 比較すると、逆打 1、2 の物件では工程進捗率 70 80\% 時点の発生 量割合が在来工法の物件よりも高く、早い時期に廃棄物の増加が始 まっている。逆打 3 の物件は発生量割合のピークが工程進捗率 80 〜 90\%に集中しており、特異な発生パターンになっている。PCa工 法採用の効果として、躯体工事から発生する廃棄物の抑制が考えら れるが、 $\mathrm{PCa}$ による積層工法の施工時期が仕上工事期間と重複して いるため、これらのデータから確認することはできなかった。

\section{4. 主要な廃棄物種類の発生パターン}

多品目分別を徹底したゼロエミッションモデル現場（物件 A）注3) の実績データを調査し、具体的な廃棄物種類の発生パターンを分析 する。なお、この物件は前述のサンプルデータには含まれていない。

\section{1 物件 $A$ の建物概要}

所在地 : 東京都、工期 : 33 ヶ月

建物用途: 事務所、構造: S 造 地上 : 38 階 地下 3 階 延床面積 : $253,400 \mathrm{~m}^{2}$ 工法 : 逆打工法

物件 $\mathrm{A}$ は 111 品目の廃棄物を徹底分別し $3 \mathrm{R}$ を推進した結果、混 合廃棄物の割合をわずか $14 \%$ （容積比）に抑制した。そのため単品 で排出された廃棄物の割合が多く、詳細な分別品目ごとの排出実績 を得ることができた。

\section{2 工事期間区分別の各廃棄物種類の割合}

111 品目の廃棄物のうち新聞や雑誌などの事業系一般廃棄物（16 品目）とリユース品（5 品目）を除いた産業廃棄物 90 品目を、表 6 に示寸廃棄物種類に分類して分析を行った。図 25 に工事期間区分 別の発生量割合と各廃棄物種類が占める割合を示す。仕上工事期間

（躯体工事の重複期間含む）からの廃棄物の発生量割合が $92 \%$ を占 めている。これは 3.4(3)で得られた結果と同様の傾向であり、逆打

表 6 廃棄物種類の内訳

\begin{tabular}{|c|c|}
\hline 廃棄物種類 & 分別品目 (全95品目) \\
\hline コンクリート・がれき類 & コンクリート、アスコン、その他がれき類 全3品目 \\
\hline 石䯧ボード & 異物付、メーカー別石膏ボード 全3品目 \\
\hline ガラス陶磁器くず & ケイカル板、岩綿吸音板、ALC、タイル、ガラス他 全20品目 \\
\hline 金属くず & 鉄くず、電線、缶類、スプレー、シュレッダー他 全7品目 \\
\hline 廃プラスチック & 硬質、軟質、PPバンド、塩ビ管、CD管、クロス他 全40品目 \\
\hline ダンボール(紙くず) & 搬出先別、セメント袋、包装紙他 全5種類 \\
\hline 木くず(単品) & 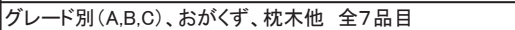 \\
\hline 混合廃棄物·その他 & 安定型、管理型、ダスト他 全10品目 \\
\hline
\end{tabular}




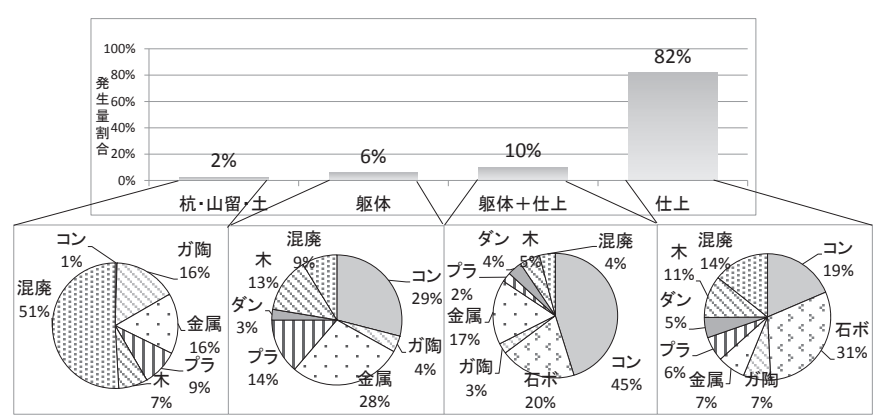

図 25 工事期間区分別の各廃棄物の割合

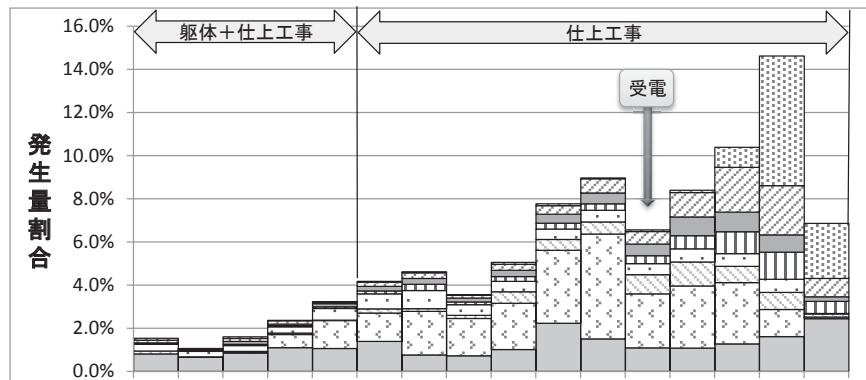

工程淮㑕率

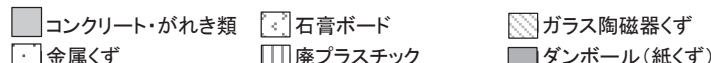

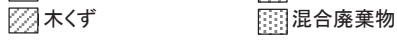

図 26 仕上工事期間中の各廃棄物種類の発生割合

工法を採用していることが理由の一つであると考えられる。各工事 期間区分の各廃棄物種類の割合は、杭・山留・土工事で混合廃棄物 の割合が高く、躯体工事ではコンクリートと金属くずの割合が高い。 躯体十仕上工事ではコンクリートと金属に加えて石膏ボードの割合 が高くなっている。また廃棄物の大半を占める仕上工事では石膏ボ ードの割合が最も高い。躯体十仕上工事（工程進捗率 $55 \%$ 時点）以 降に発生した廃棄物種類別の発生量割合（全廃棄物発生量を $100 \%$ とする)を図 26 に示す。排出量割合のピークは工程進捗率 90〜 $100 \%$ の時点であり、竣工直前の排出量が多かったことが分かる。廃棄物 種類ごとの特徵を見ると、最も多く発生している石膏ボードは仕上 工事期間を通して発生しており、特に受電前の時期の発生量が多い。 木くずは受電の前後から発生量が増加している。これらは仕上工事 が完了した部分の養生材や設備機器の搬入時に使用される木枠によ るものであると考えられる。ダンボールは発生量の数值が小さいが、 これは圧縮機による減容化の効果であり、空隙を含んだ状態では約 $3 \sim 4$ 倍（現場実測値）の体積に増加するため、仕上工事期間にお いて重点管理が必要な廃棄物であると言える。コンクリートは躯体 工事だけでなく仕上工事においても定常的に発生している。仕上工 事に必要な躯体の斫り作業によるもの、駄目穴や機械台の打設時の 既設配管内の残コンなどが発生していると考えられる。

以上のことから仕上工事期間中に発生する廃棄物の中では石膏ボ ード、木くず、ダンボール、コンクリートの割合が高く、これらの 品目の発生時期を考慮した廃棄物計画が重要であると考えられる。

\section{5. まとめ}

本研究で得られた知見を以下に示す。

・廃棄物発生量の増加時期は工期の長さによる影響が強く、工期が 長いほど、発生量が遅い時期に上昇寸る傾向が見られる。

-地下階の無い物件は比較的工期の短い物件が多く、早い時期に廃
棄物発生量の上昇傾向が見られる。また地下階が無い物件は躯体 工事の開始時期は早くなるが、仕上工事の開始時期に地下階の有 無は影響しない。

・建物用途別および構造別による廃棄物発生パターンは、事務所、 集合住宅、教育施設において大きな差異が見られない。

・サンプル物件による分析を行なった結果、廃棄物の発生原単位が 同程度である事務所、集合住宅、教育施設の建物用途では工程進 捗率 $50 \sim 60 \%$ の時点から仕上工事が開始され、廃棄物の約 $80 \%$ が仕上工事期間に発生している。また、工程進捗率 80〜90\%の時 点で廃棄物の発生割合がピークを迎える場合が多い。

・廃棄物の発生原単位が小さい工場は仕上工事の開始時期がやや早 く、廃棄物の発生のピークとなる時期は、短期間に集中するので はなく徐々に増加する傾向がある。

・逆打工法を採用した物件では、躯体と仕上工事の重複期間が長く、 仕上工事期間の発生量割合は 82～92\% と在来工法の物件よりも 割合が高くなる。また在来工法より早い時期に廃棄物の増加が始 まる傾向がある。

・ゼロエミッションモデル現場の実績から具体的な廃棄物種類の発 生量割合を分析した結果、建築廃棄物の大半を占める仕上工事期 間中に発生する廃棄物は、石膏ボード、木くず、ダンボール、コ ンクリートの割合が高く、これらの品目の発生時期を考慮した廃 棄物計画が重要である。

本研究では廃棄物の排出実績を基に、建築廃棄物と工事工程の関 連性について考察した。現場で発生した廃棄物はストックヤードで 保管されている期間があり、実際の発生時期と排出時期にはタイム ラグが存在している。今後は廃棄物種類ごとの容器サイズやストッ クヤードの面積などの調查により、保管可能な期間を考慮した廃棄 物の発生時期に関する検証が必要であると考える。

\section{参考文献}

1) 名知洋子・宮崎隆昌：建築生産プロセスにおける建設副産物の排出要因と 混合廃棄物量に関する一考察, 日本建築学会技術報告集 第 18 号, pp325-328, 2003. 12

2）小川由美子・深堀秀俊・高偉俊 : 北九州市における建築廃棄物及び再資源 化に関する調查研究, 日本建築学会大会学術講演梗概集. D-1, pp767-768, 2004. 8

3) 社団法人建築業協会環境委員会副産物部会 : 建築系混合廃棄物の原単位調 査報告書, pp 10, 2011.2

4) 室谷泰蔵・古阪秀三・金多隆 : 在来型建築工事における工程計画作成に関 する研究, 日本建築学会計画系論文集 第 582 号, pp109-116, 2004.8

5) 志手一哉・湯浅洋一・蟹澤宏剛・山本将太 : 集合住宅の内装仕上工事にお ける工程パターンの分析, 日本建築学会技術報告集 第 30 号, pp557-562, 2009.6

6) 伊藤永三郎・田村恵彦・内藤正光 : 建設副産物総合管理システムの開発と 運用, 日本建築学会建築生産シンポジウム梗概集 第 13 回, pp7-14, 1997. 7

注

注 1） 1998 年より稼働された政府が管轄する電子版のマニフェスト。筆者ら は建設業界の特性に合致した導入モデルを構築し、2012 年 5 月現在、 約 400 の建設会社において当導入モデルが採用されている。

注 2）構造体や外壁などを 1 層ずつ組み立て、順次上方へ積上げていく工法。

注 3) 国内の建築事業における最高レベルのゼロエミッション活動が認めら れ 2008 年度 $3 R$ 推進等表彰にて国土交通大臣賞を受賞した。

（2012年 5 月10日原稿受理，2012年10月29日採用決定） 